\title{
Implementasi Green Accounting, Profitabilitas dan Corporate Social Responsibility pada Nilai Perusahaan
}

\author{
Putu Purnama Dewi ${ }^{1}$ \\ Fakultas Ekonomi dan Bisnis \\ Universitas Pendidikan Nasional, \\ Indonesia
}

\author{
I Putu Edward Narayana ${ }^{2}$ \\ Fakultas Ekonomi dan Bisnis \\ Universitas Pendidikan Nasional, \\ Indonesia
}

Surel : purnamadewi@undiknas.ac.id

\section{ABSTRAK}

Tujuan dari penelitian ini adalah untuk mengetahui pengaruh implementasi green accounting, profitabilitas, dan corporate social responsibility terhadap nilai perusahaan. Sampel dari penelitian ini adalah perusahaan pertambangan yang terdaftar di Bursa Efek Indonesia (BEI) periode 2015 - 2019. Data yang digunakan adalah data sekunder yang berupa environmental cost, return on equity, CSR Indeks, dan Tobins'Q. Data tersebut diperoleh dari situs Bursa Efek Indonesia dan situs perusahaan terkait. Hasil penelitian ini menunjukan bahwa pengaruh terhadap green accounting berpengaruh positif terhadap nilai perusahaan, hal ini diperoleh dari nilai signifikansi sebesar 0,003 dengan nilai koefisien beta 0,228 . Profitabilitas juga memiliki pengaruh positif terhadap nilai perusahaan adalah pengaruh yang positif, hal ini ditunjukkan oleh nilai signifikansi sebesar 0,000 dengan nilai koefisien beta 0,724 . Pengaruh corporate social responsibility terhadap nilai perusahaan juga menunjukkan arah yang positif, yang ditunjukkan dari nilai signifikansi sebesar 0,011 dengan nilai koefisien beta 0,210 bernilai positif.

Kata Kunci: Green Accounting; Profitabilitas; Corporate Social Responsibility; Nilai Perusahaan.

\section{Implementation of Green Accounting, Profitability and Corporate Social Responsibility for Corporate Values}

\section{ABSTRACT}

The purpose of this study is to determine the effect of the implementation of green accounting, profitability, and corporate social responsibility on firm value. The sample of this study is mining companies listed on the Indonesia Stock Exchange (IDX) for the period 2015 - 2019. The data used are secondary data in the form of environmental cost, return on equity, CSR Index, and Tobins'Q. The data is obtained from the Indonesia Stock Exchange website and related company websites. The results of this study indicate that the effect on green accounting has a positive effect on firm value, this is obtained from a significance value of 0.003 with a beta coefficient value of 0.228 . Profitability also has a positive influence on firm value is a positive influence, this is indicated by a significance value of 0.000 with a beta coefficient value of 0.724 . The effect of corporate social responsibility on firm value also shows a positive direction, as indicated by a significance value of 0.011 with a positive beta coefficient value of 0.210 .

Keywords: Green Accounting; Profitability; Corporate Social Responsibility; Firm Value.

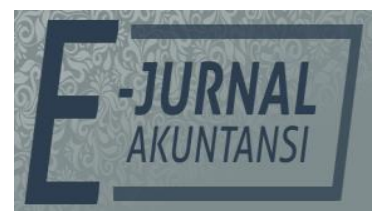

e-ISSN 2302-8556

Vol. 30 No. 12

Denpasar, Desember 2020

Hal. 3252-3262

DOI:

10.24843/EJA.2020.v30.i12.p20

PENGUTIPAN:

Dewi, P.P. \& Narayana, I

P.E. (2020). Implementasi

Green Accounting,

Profitabilitas dan Corporate Social Responsibility pada

Nilai Perusahaan. E-Jurnal

Akuntansi, 30(12), 3252-3262

RIWAYAT ARTIKEL: Artikel Masuk: 27 Agustus 2020 Artikel Diterima: 14 Desember 2020

Artikel dapat diakses : https://ojs.unud.ac.id/index.php/Akuntansi/index 


\section{PENDAHULUAN}

Isu mengenai lingkungan dan sumber daya alam semakin berkembang selama dua dekade terakhir ini. Berbagai permasalahan lingkungan seperti polusi udara, pemanasan global, penipisan lapisan ozon, pencemaran air serta eksploitasi alam secara berlebihan telah menarik perhatian bangsa dan menjadi sorotan dunia internasional. Pemerintah sebagai pemangku kebijakan telah mengupayakan berbagai langkah yang tepat untuk mengatasi permasalahan tersebut dalam usaha mewujudkan pembangunan berkelanjutan (Agustina, 2013).

Sejalan dengan hal tersebut, kepedulian masyarakat akan kelestasrian lingkungan juga semakin meningkat menjadi pendorong perusahaan untuk selalu memperhatikan tanggung jawab sosial dan lingkungannya kepada stakehoklder khususnya para pemegang saham, kreditur serta masyarakat luas. Sesuai dengan konsep triple bottom lines bahwa selain mencari keuntungan (profit), perusahaan juga perlu memikirkan mengenai lingkungan sekitarnya (planet) dan kepada para pemangku kepentingan (people). Dengan memperhatikan konsep tersebut, diharapkan mampu meningkatan nilai perusahaan serta meningkatkan kesejahteraan pemegang saham dengan memperhatikan potensi finansial dan non finansial supaya eksistensi perusahaan tetap terjaga.

Nilai perusahaan merupakan salah satu indikator utama dalam menjaring investasi untuk pengembangan perusahaan. Nilai perusahaan adalah nilai pasar saham yang menunjukkan keadaan saat ini atau prospek perusahaan di masa mendatang. Perusahaan yang banyak melakukan investasi akan menciptakan sentimen positif kepada investor sehingga harga saham akan meningkat dan berdampak pada nilai perusahaan (Wijaya, B.I., Sedana, 2015). Nilai saham suatu perusahaan tentunya dipengaruhi oleh beberapa faktor diantaranya green accounting melalui pengungkapan lingkungan, rasio profitabilitas perusahaan serta pengungkapan corporate social responsibility (CSR) oleh perusahaan.

Dewasa ini, setiap industri dituntut untuk dapat menerapkan green accounting sebagai bagian dari tanggung jawab perusahaan terhadap lingkungan. Penerapan green accounting merupakan salah satu metode yang memperhitungkan sumber daya dan jasa lingkungan serta perubahan dalam upaya meningkatkan pendapatan dan mempertahankan pembangunan serta pertumbuhan berkelanjutan dengan memperhatikan kebutuhan saat ini dan masa yang akan dating (Himanshu, 2010). Green accounting adalah penerapan akuntansi dimana perusahaan juga memasukkan biaya-biaya untuk pelestarian lingkungan yang sering disebut dengan istilah biaya lingkungan dalam beban usaha. Namun dalam kenyataannya, masih banyak terdapat perusahaan yang belum menerapkan metode ini.

Green accounting merupakan salah satu konsep kontemporer dalam akuntansi yang mendukung Gerakan hijau di perusahaan dengan mengenali, mengkuantifikasi, mengukur dan menutup kontribusi lingkungan hidup terhadap proses bisnis (Fauzi \& Chandra ,2016). Apabila diterapkan dalam jangka panjang, konsep green accounting sebenarnya adalah program untuk penghematan biaya produksi sehingga dapat mengurangi beban operasional perusahaan. Pada era dimana masyarakat telah sangat sadar akan pentinganya 
pelestarian lingkungan, penerapan green accounting oleh industri dapat menjadi daya tarik tersendiri bagi konsumen. Pemerintah Indonesia melalui Kementerian Perindustrian juga memberi penghargaan terhadap perusahaan yang mampu menerapkan industri hijau setiap tahunnya. Kementerian Lingkungan Hidup juga telah melaksanakan PROPER yaitu Program Penilaian Peringkat Kinerja Perusahaan dalam pengelolaan lingkungan hidup.

Demikian juga halnya dengan profitabilitas yang dianggap penting dalam perkembangan sebuah usaha karena profitabilitas sebagai indikator dalam mengukur kinerja keuangan suatu perusahaan sehingga dapat dijadikan acuan untuk menilai perusahaan. Rasio profitabilitas menggambarkan kemampuan perusahaan untuk mendapatkan laba melalui semua kemampuan dan sumber yang ada seperti kegiatan penjualan, kas, modal, jumlah karyawan dan sebagainya (Khairudin \& Wandita, 2017). Apabila perusahaan dapat menghasilkan profit yang baik maka menunjukkan performa perusahaan yang baik, mengidikasikan bahwa perusahaan memiliki nilai yang baik dan menjamin prospek masa depan. Untuk mengukur profitabilitas dapat menggunakan beberapa ratio diantaranya adalah return on equity ratio (ROE).

Menurut UU Perseroan Terbatas No. 40 Tahun 2007 pasal 74, Perseroan yang menjalankan usaha berkaitan dengan sumber daya alam diwajibkan untuk melaksanakan program CSR. Indikator penerapan CSR dapat diketahui melalui pengungkapan pada laporan keberlanjutan perusahaan. Penilaian CSR sebuah perusahaan dapat dibantu dengan GRI (Global Reporting Initiative) yang berfokus pada indikator kinerja ekonomi, indikator kinerja lingkungan, dan indikator kinerja sosial. Dengan hubungan yang baik antara perusahaan dan lingkungan sekitar akan memberikan dampak yang positif terhadap sustainability perusahaan.

Dalam kaitannya dengan hal diatas, penelitian ini akan menggunakan sampel perusahaan tambang karena perusahaan tambang merupakan salah satu usaha yang berpengaruh besar terhadap lingkungan dan keberlangsungan hidup sekitar. Asumsi tersebut muncul karena perusahaan tambang termasuk perusahaan yang secara langsung melakukan eksplorasi dan eksploitasi sumber daya alam yang menyebabkan kerusakan lingkungan sehingga berpengaruh pada kehidupan masyarakat, dimana semakin besar skala kegiatan perusahaan maka semakin besar pula dampaknya bagi lingkungan sekitar.

Dalam menjalankan bisnisnya perusahaan tidak hanya memikirkan kepentingan pihak internal namun juga perlu memikirkan kepentingan dari pihak eksternal perusahaan yaitu masyarakat sekitar dan lingkungannya. Perusahaan dapat menggunakan disclosure untuk menarik perhatian manajemen akan nilai sosial, atau untuk mengarahkan kembali perhatian akan pengaruh negatif akibat aktivitas bisnis.

Teori stakeholder menekankan kepada sebuah organisasi, grup, atau individu yang dapat dipengaruhi dan mempengaruhi tujuan organisasi tersebut. Pengungkapan informasi keuangan, sosial, dan lingkungan merupakan dialog antara perusahaan dengan stakeholder dan menyediakan informasi mengenai aktivitas perusahaan yang dapat mengubah persepsi dan ekspektasi. Teori stakeholder merupakan suatu teori yang menyatakan bahwa keberlangsungan perusahaan sangat dipengaruhi oleh peran stakeholder. CSR dapat menjadi 
perantara antara perusahaan dengan stakeholder. Pengungkapan CSR merupakan suatu bentuk tanggung jawab perusahaan terhadap stakeholder. Dukungan dari stakeholder sangat diperlukan untuk menjamin sustainability perusahaan dalam meningkatkan kinerja dan nilai perusahaan.

Penelitian sebelumnya oleh Astuti (2012) menyatakan green accounting memiliki tujuan yang berkaitan dengan kegiatan-kegiatan konservasi lingkungan oleh perusahaan maupun organisasi lainnya, yaitu mencakup kepentingan perusahaan dan organisasi. Hasil penelitian oleh Zulhaimi (2015) juga menemukan bahwa penerapan green accounting dapat mempengaruhi keputusan shareholder dan investor. Setelah penerapan green accounting terdapat kenaikan earning dan harga saham namun tidak signifikan. Tu \& Huang (2015) dalam penelitian terhadap perusahaan Taiwan yang telah bersertifikat ISO14000 (Environmental Management) menyatakan bahwa green accounting melalui environmental costs akan memiliki pengaruh negatif terhadap profitabilitas (return on assets, return on equity, dan net operating profit), namun dapat meningkatkan daya saing dan sustainabilitas perusahaan. Ezeagba, Rachael, \& Chiamaka (2017) dalam penelitiannya terhadap perusahaan makanan dan minuman menemukan bahwa environmental accounting berpengaruh signifikan terhadap Return on Equity. Berdasarkan beberapa hasil dari penelitian tersebut, maka hipotesis pertama pada penelitian ini dapat dirumuskan sebagai berikut.

$\mathrm{H}_{1}$ : Penerapan green accounting berpengaruh signifikan terhadap nilai perusahaan.

Sabrin et al., (2016) dalam penelitiannya pada perusahaan manufaktur di Indonesia menemukan bahwa profitabilitas memiliki pengaruh positif terhadap nilai perusahaan, dimana profit tersebut digunakan untuk untuk pembayaran dividen. Harga saham akan meningkat karena perusahaan memberikan sinyal positif berupa pembagian dividen. Menurut Irfandi (2015), profitabilitas berpengaruh positif signifikan terhadap nilai perusahaan. Hal ini disebabkan perusahaan yang mengalami peningkatan laba menceminkan bahwa perusahaan mempunyai kinerja yang baik, sehingga menimbulkan sentimen positif dari investor. Susila \& Prena (2019) juga mengungkapkan bahwa semakin tinggi tingkat profitabilitas yang dicapai suatu perusahaan, nantinya akan menjadi suatu pertimbangan bagi investor untuk menanamkan modalnya di perusahaan tersebut. Berdasarkan penelitian tersebut, peneliti ingin menguji kembali pengaruh antara profitabilitas dengan nilai perusahaan, maka hipotesis kedua darlam penelitian ini dirumuskan sebagai berikut.

$\mathrm{H}_{2}$ : Profitabilitas berpengaruh signifikan terhadap nilai perusahaan.

Nahda \& Marjito (2011) dalam penelitiannya menemukan bahwa CSR berpengaruh positif dan signifikan terhadap nilai perusahaan, karena semakin baik penerapan CSR maka nilai perusahan akan semakin meningkat. Hafez (2016) juga menyatakan bahwa CSR memiliki pengaruh positif signifikan terhadap nilai perusahaan yang diwakili oleh ROE dan ROA. Dalam hal ROA, investor lebih senang berinvestasi pada perusahaan yang memaksimalkan modal yang diberikan. Sedangkan dalam konteks ROE, apabila perusahaan menerapkan CSR, mereka akan lebih efisien dalam mengatur aset dimana dapat meningkatkan ROA perusahaan secara keseluruhan. Berdasarkan asumsi tersebut maka hipotesis ketiga pada penelitian ini adalah sebagai berikut. 
$\mathrm{H}_{3}$ : Corporate social responsibility berpengaruh signifikan terhadap nilai perusahaan.

Sesuai dengan pemaparan hipotesis tersebut maka model penelitian ini dapat digambarkan sebagai berikut.

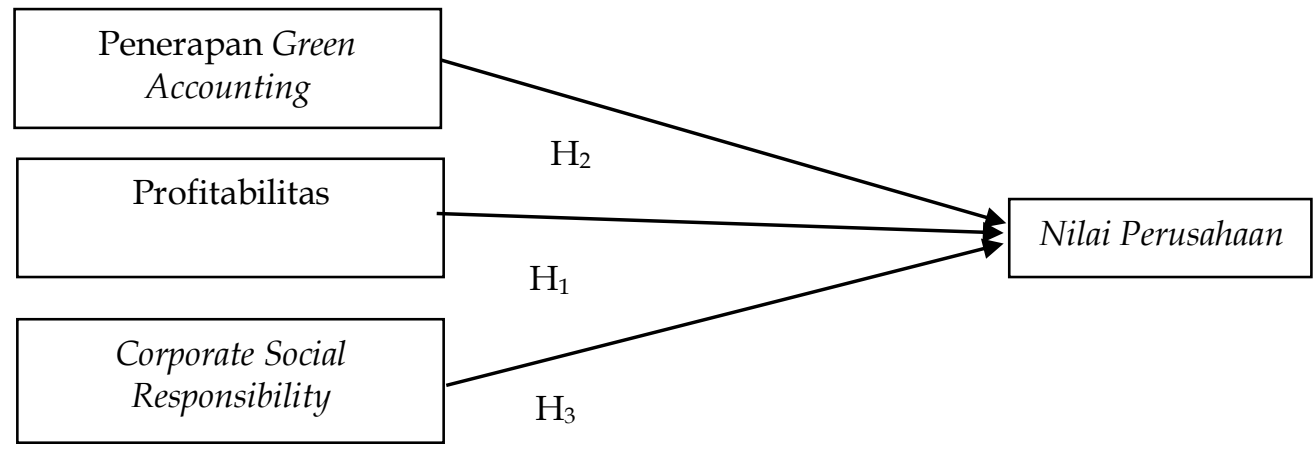

Gambar 1. Model Penelitian

Sumber: Data Penelitian, 2020

\section{METODE PENELITIAN}

Sampel adalah bagian dari jumlah dan karakteristik yang dimiliki oleh populasi (Sugiyono, 2009). Sesuai dengan karakteristik masalah yang diteliti, penelitian ini menggunakan data perusahaan pertambangan yang sudah terdaftar di Bursa Efek Indonesia periode 2015-2019 dengan kriteria sampel yaitu perusahaan telah mempublikasi laporan keuangan tahunan dan telah menerbitkan laporan keberlanjutan (Sustainability Report). Sumber data dalam penelitian ini adalah data sekunder yaitu berupa annual report pada periode 2015-2019 dan data ini termasuk kedalam jenis data kuantitatif.

Dalam mengukur nilai perusahaan pada penelitian ini akan digunakan Tobins'q. Rasio ini merupakan konsep yang sangat berharga karena menunjukkan estimasi pasar keuangan saat ini tentang nilai hasil pengembalian dari setiap investasi. Rasio tobins'q dipilih dalam pennelitian ini karena mampu mencerminkan aktiva perusahaan secara komprehensif, mampu mencermminkan sentimen pasar seperti prospek perusahaan, dan dapat mencerminkan intellectual capital perusahaan. Jika nilai Tobins'q perusahaan lebih besar dari satu maka perusahaan dianggap overvalued, sedangkan apabila kurang dari satu maka perusahaan dianggap undervalued. Rumus Tobins'q adalah sebagai berikut.

Tobins' $\mathrm{q}=$ MVS - TL.

Keterangan :

MVS = Market value of all outstanding shares

$\mathrm{TL} \quad=$ Total Liabilities

TA $\quad=$ Total Assets

Ahmad et al., (2018) menyatakan green accounting merupakan proses pengungkapan informasi terkait dengan environmental performance yang menunjukkan akuntabilitas aktivitas bisnis perusahaan. Dalam penelitian ini environmental cost yang dilaporkan perusahaan akan digunakan sebagai indikator 
dari penerapan green accounting. Environmental cost merupakan biaya yang dikeluarkan perusahaaan untuk keperluan environment protection.

Westerfield, Brandford, \& Jordan (2008) dalam penelitiannya mengungkapkan terdapat tiga ukuran paling dikenal dan paling luas penggunaannya yaitu Net Profit Margin, Return on Assets, dan Return on Equity. Ketiga rasio diatas dimaksudkan unutk mengukur seberapa efisien sebuah perusahaan telah menggunakan asset dan mengelola operasinya. Fokus dari kelompok ini adalah pada hasil akhir yaitu laba bersih. Pada penelitian ini, rasio yang akan digunakan adalah rasio Return on Equity (ROE). ROE adalah ukuran dari hasil yang diperoleh pemegang saham sepanjang tahun. Dihitung dengan cara sebagai berikut.

$$
\text { ROE }=\frac{\text { Laba Bersih......... }}{\text { Total Equitas }}
$$

CSR merupakan tanggung jawab perusahaan terhadap lingkungan sosial yang ada di sekitarnya. Dengan reputasi yang baik di lingkungan sosial, maka akan mempermudah kegiatan operasional perusahaan. Dengan kemudahan tersebut, diharapkan perusahaan dapat berproduksi dengan efektif dan efisien dalam mencapai tujuan. Dalam penelitian ini CSR berpedoman pada GRI Sustainability Reporting Standards yang akan dihitung dengan cara ini adalah

$$
C_{\text {SRI }}=\frac{\sum \mathrm{X}_{\mathrm{ij}}}{n_{j}}
$$

Keterangan :

CSRI = Corporate Social Responsibility Index perusahaan.

$\sum \mathrm{Xi}=$ Dummy Variabel; $1=$ jika item diungkapkan; $0=$ jika item tidak Diungkapkan.

$\mathrm{n} \quad=$ Jumah keseluruhan item

\section{HASIL DAN PEMBAHASAN}

Melalui metode purposive sampling terdapat sebanyak 40 sampel yang telah memenuhi kriteria yang diambil dari laporan keuangan tahunan dan laporan keberlanjutan perusahaan tambang yang terdaftar di Bursa Efek Indonesia.

Dalam penelitian ini uji asumsi klasik yang digunakan adalah uji normalitas, multikolineritas, autokorelasi dan heterokedastisitas. Dari hasil pengujian yang telah dilakukan data penelitian ini ditunjukkan bahwa telah terbebas dari asumsi klasik. Analisis yang digunakan untuk mengetahui pengaruh variabel bebas terhadap variabel terikat dalam penelitian ini adalah analisis regresi linier berganda (Sujarweni, 2015).

Berdasarkan hasil perhitungan adjusted $R$ Square pada Tabel 1, telah memperoleh nilai koefisien determinasi $\mathrm{R}^{2}$ sebesar 0,824 atau $82,4 \%$. Hal ini berarti kemampuan seluruh variabel independen yang terdiri dari penerapan green accounting, profitabilitas, dan corporate social responsibility dalam menjelaskan variabel dependen yaitu nilai perusahaan pada perusahaan tambang yang terdaftar di Bursa Efek Indonesia tahun 2015-2019 sebesar 82,4\% sisanya $18,6 \%$ dipengaruhi oleh variabel lain yang tidak diteliti dalam penelitian ini. 
Tabel 1. Uji Koefisien Determinasi

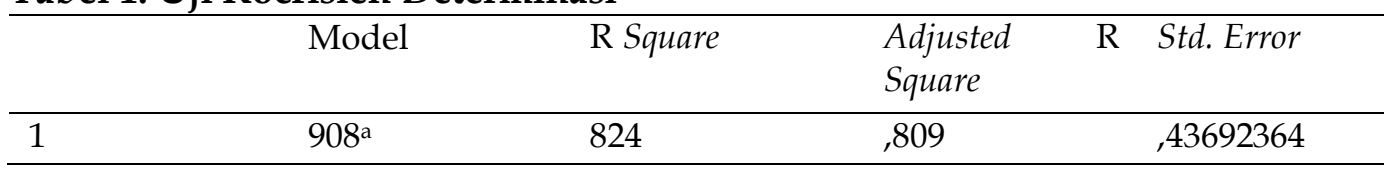

Sumber: Data Penelitian, 2020

Pada Tabel 2, dapat dilihat hasil nilai signifikasi pada uji f anova sebesar 0,000 dengan nilai hitung $\mathrm{f}$ anova sebesar 56,098. Dari hasil tersebut di ketahui bahwa nilai signifikan $\mathrm{F} 0,000<0,05$ yang berarti penerapan green accounting, profitabilitas dan corporate social responsibility terhadap nilai perusahaan.

Tabel 2. Uji F Anova

\begin{tabular}{lllllll}
\hline & Model & $\begin{array}{c}\text { Sum of } \\
\text { Squares }\end{array}$ & df & Mean & F & Sig. \\
\hline 1 & Regression & 32,128 & 3 & 10,079 & 56,098 & $0,000^{\mathrm{b}}$ \\
& Residual & 6,872 & 36 & 0,191 & & \\
& Total & 39,000 & 39 & & & \\
\hline
\end{tabular}

Sumber: Data Penelitian, 2020

Hasil pengujian hipotesis dilakukan dengan menggunakan regresi berganda pada Tabel 3.

Tabel 3. Hasil Regresi Berganda

\begin{tabular}{|c|c|c|c|c|c|c|}
\hline & \multirow[t]{2}{*}{ Model } & \multicolumn{2}{|l|}{$\begin{array}{l}\text { Unstandardized } \\
\text { Coefficients }\end{array}$} & $\begin{array}{l}\text { Standardized } \\
\text { Coefficients }\end{array}$ & \multirow[b]{2}{*}{$\mathrm{t}$} & \multirow[b]{2}{*}{ Sig } \\
\hline & & B & $\begin{array}{l}\text { Std. } \\
\text { Error }\end{array}$ & Beta & & \\
\hline \multirow[t]{4}{*}{1} & (Constant) & 6,570 & ,069 & & 0,000 & 1,000 \\
\hline & $\mathrm{X} 1$ & ,228 & ,072 & 228 & 3,172 & ,003 \\
\hline & $\mathrm{X} 2$ & ,724 & ,080 & ,724 & 9,074 & ,000 \\
\hline & $\mathrm{X} 3$ & ,210 & ,078 & 210 & 2,689 & ,011 \\
\hline
\end{tabular}

Sumber: Data Penelitian, 2020

Berdasarkan Tabel 3, $\mathrm{H}_{1}$ menunjukan adanya pengaruh penerapan green accounting terhadap nilai perusahaan diperoleh nilai sig.t sebesar yaitu 0,003 dengan nilai koefisien beta 0,228 mengindikasikan bahwa $\mathrm{H}_{0}$ ditolak dan $\mathrm{H}_{1}$ diterima. Jadi sesuai dengan hasil tersebut untuk variabel green accounting dinyatakan berpengaruh positif dan signifikan terhadap nilai perusahaan. Dengan kata lain semakin meningkat green accounting akan semakin meningkatkan nilai perusahaan, sebaliknya jika green accounting semakin menurun maka nilai perusahaan akan semakin menurun. Dengan adanya pengaruh positif dan signifikan antara green accounting dengan nilai perusahaan, maka sesuai dengan Environmental Accounting Guidelines yang dikemukakan oleh Menteri Lingkungan Hidup Jepang, yang menyatakan green accounting merupakan suatu penilaian kuantitatif terhadap biaya dan efektifitas perlindungan lingkungan sehingga perusahaan perlu memiliki catatan dan laporan mengenai aktivitas lingkungan dengan tujuan untuk meningkatkan nilai perusahaan dan mencapai pembangunan yang berkelanjutan.

Hal senada juga diungkapkan oleh Hanifa Zulhaimi (2015) yang menyatakan bahwa terdapat kenaikan earning dan harga saham setelah penerapan green accounting. Variabel kinerja lingkungan merupakan salah satu 
variabel yang dapat mempengaruhi kinerja keuangan khususnya harga saham. Kinerja lingkungan juga merupakan salah satu indikator ketaatan perusahaan terhadap peraturan-peraturan yang ada di Indonesia khusunya dalam bidang lingkungan. Kinerja keuangan dengan nilai perusahaan memiliki hubungan yang searah artinya semakin baik kinerja keuangan perusahaan maka akan diikuti dengan naiknya nilai perusahaan.

Ditinjau dari hasil tersebut dapat disimpulkan bahwa pada periode 20152019 perusahaan tambang telah melakukan pengelolaan dengan baik untuk lingkungan yang terkena dampak dari kegiatan operasionalnya. Tentu ini mampu menunjukan bahwa perusahaan tambang tidak hanya sebatas melakukan ekplorasi dan eksploitasi bagi lingkungan namun juga secara seimbang memperbaiki dan mengelola lingkungan sesuai dengan kebutuhan lingkungan. Dengan terciptanya lingkungan yang baik, perusahaan juga telah memenuhi kontrak sosialnya dengan masyarakat, sehingga tidak ada pihak yang dirugikan karena perusahaan sebagai pihak yang beroperasi telah melakukan upaya terbaik bagi lingkungan sekitar masyarakat tinggal dan masyarakat tidak perlu menerima dampak kerusakan lingkungan yang disebabkan oleh perusahaan.

Hasil analisis $\mathrm{H}_{2}$, pengaruh profitabilitas terhadap nilai perusahaan diperoleh nilai sig.t sebesar 0,000 dengan nilai koefisien beta 0,724 yang mengindikasikan bahwa $\mathrm{H}_{0}$ ditolak dan $\mathrm{H}_{1}$ diterima. Hasil ini menunjukan bahwa profitabilitas berpengaruh positif signifikan terhadap nilai perusahaan. semakin meningkat profitabilitas akan semakin meningkatkan nilai perusahaan, sebaliknya jika profitabilitas semakin menurun maka nilai perusahaan akan semakin menurun. Rasio profitabilitas merupakan rasio yang mengungkapkan kemampuan perusahaan dalam memperoleh laba dalam hubungannya dengan penjualan maupun modal sendiri yang akan menghasikan nilai bagi perusahaan, sehingga dapat menjadi acuan bagi investor jangka panjang. Return on equity adalah salah satu perhitungan yang sangat penting pada suatu perusahaan, dimana ROE yang tinggi dan konsisten mengindikasikan perusahaan memiliki keuggulan dan investasi dalam bentuk modal pemegang saham akan terus mengalami pertumbuhan.

Sabrin et al., (2016) dalam penelitian pada perusahaan manufaktur di Indonesia menemukan bahwa profitabilitas memiliki pengaruh positif terhadap nilai perusahaan, dimana profit tersebut digunakan untuk untuk pembayaran dividen. Harga saham akan meningkat karena perusahaan memberikan sinyal positif berupa pembagian dividen.

Hasil analisis $\mathrm{H}_{3}$, pengaruh corporate social responsibility terhadap nilai perusahaan diperoleh nilai sig.t sebesar 0,011 dengan nilai koefisien beta 0,210. Nilai Sig. t 0,011 < 0,05 mengindikasikan bahwa $\mathrm{H}_{0}$ ditolak dan $\mathrm{H}_{3}$ diterima. Dari hasil ini dapat disimpulkan bahwa corporate social responsibility berpengaruh positif signifikan terhadap nilai perusahaan. Dengan kata lain semakin meningkat corporate social responsibility akan semakin meningkatkan nilai perusahaan, sebaliknya jika corporate social responsibility semakin menurun maka nilai perusahaan akan semakin menurun. Corporate social responsibility sebagai suatu komitmen bisnis yang dapat berkontribusi dalam meningkatkan nilai perusahaan dan mewujudkan pembangunan ekonomi berkelanjutan. 
Hal ini sejalan dengan penelitian yang dilakukan (Susila \& Prena, 2019) yang menyatakan bahwa keputusan pendanaan, kebijakan dividen, profitabilitas dan corporate social responsibility berpengaruh positif dan signifikan terhadap nilai perusahaan. Hal senada juga diungkapkan oleh Nahda \& Harjito (2011) yang menyatakan bahwa CSR secara signifikan berpengaruh positif terhadap nilai perusahaan. Begitu juga hasil penelitian yang diperoleh Prihatiningtias \& Dayanti (2014) yang menemukan bahwa CSR berpengaruh positif tidak signifikan terhadap firm financial performance. Namun hasil ini berbeda dengan hasil penelitian yang dilakukan oleh Hafez (2016) yang menunjukkan bahwa CSR memiliki hubungan negatif insignifikan dengan nilai perusahaan. Sedangkan CSR berpegaruh positif signifikan terhadap financial performance. Penelitian dari Sivasubraniam (2019) yang dilaksanakan pada Bank Komersial di Srilanka menunjukkan pengaruh negatif CSR terhadap nilai perusahaan (tobins'q), berbeda apabila pengujian dilakukan pada perusahaan pertambangan yang ada di Indonesia, sehingga perbedaan sektor perusahaan juga berpengaruh terhadap hasil penelitian. CSR dari perusahaan pertambangan berpengaruh terhadap nilai perusahaan karena lokasi usaha yang berhubungan secara langsung dengan lingkungan dan masyarakat, sehingga memiliki dampak yang lebih signifikan dibandingkan dengan sektor lainnya.

\section{SIMPULAN}

Berdasarkan hasil penelitian yang telah dilakukan, dapat disimpulkan bahwa penerapan green accounting yang berpengaruh positif signifikan terhadap nilai perusahaan, ini dapat diartikan bahwa penerapan green accounting sangat diperlukan dalam penilaian kuantitatif terhadap biaya dan efektifitas perlindungan lingkungan sehingga perusahaan perlu memiliki catatan dan laporan mengenai aktivitas lingkungan dengan tujuan untuk meningkatkan nilai perusahaan dan mencapai pembangunan yang berkelanjutan. Selain itu, perhitungan rasio profitabilitas juga berpengaruh positif signifikan pada nilai perusahaan. Ini mengandung makna bahwa kemampuan perusahaan dalam memperoleh laba dalam hubungannya dengan penjualan maupun maupun modal sendiri yang akan menghasikan nilai bagi perusahaan, sehingga dapat menjadi acuan bagi investor jangka panjang. Dan juga variabel corporate social responsibility berpengaruh positif signifikan terhadap nilai perusahaan yang berarti bahwa komitmen bisnis untuk berkontribusi dalam meningkatkan nilai perusahaan dan mewujudkan pembangunan ekonomi berkelanjutan selalu dikembangkan dan ditingkatkan.

Saran untuk penelitian selanjutnya dapat menggunakan sampel perusahaan lain agar dapat membandingkan hasil dari pengaruh penerapan green accounting, profitabilitas dan corporate social resposnsibility pada sampel perusahaan lain. Serta penelitian selanjutnya diharapkan dapat menambahkan variabel yang berkaitan dengan pengungkapan tanggung jawab sosial.

\section{REFERENSI}

Astuti, N.Permana.(2012). Mengenai Green Accounting. E-journal upstegal.

Ezeagba, C. E., Rachael, J.-A. C., \& Chiamaka, U. (2018). Environmental Accounting Disclosures and Financial Performance: A Study of selected Food and Beverage 
Companies in Nigeria (2006-2015). International Journal of Academic Research in Business and Social Sciences, 7(9), 162-174.

Fauzi, N., \& Chandra, N. (2016). green accounting dan Efektifitas Peraturan Pemerintah No 47 tahun 2012 pada Perusahaan di Indonesia. (47), 15-16.

Hafez, H. (2016). Corportae Social Responsibility and Firm Value: an Empirical Study of an Emerging Economy. Journal of Governance and Regulation, 5(4), 40-53.

Himashu S. R. (2010). Green Accounting : Issues and Challenges. The IUP Journal of Managerial Economics.

Irfandi, B.W., Sedana, I.B.Panji, (2015). Pengaruh Profitabilitas Tehadap Nilai Perusahaan (Kebijakan Deviden \& Kesempatan Investasi Sebagai Variabel Mediasi). E-Jurnal manajemen Udayana, Volume 4 (12).

Khairudin, \& Wandita. (2017). Analisis Pengaruh Rasio Profitabilitas, Debt To Equity Ratio (DER) dan Price to Book Value (PBV) Terhadap Harga Saham Perusahaan Pertambangan di Indonesia. Jurnal Akuntansi \& Keuangan, 8(1), 68-84.

Nahda, K., \& Harjito, D. A. (2011). Pengaruh Corporate Social Responsibility Terhadap Nilai Perusahaan Dengan Corporate Governance. Jurnal Siasat Bisnis, 15(1), 1-12.

P Hanifa Zulhaimi, K. (2015). Pengaruh Penerapan green accounting. Jurnal Riset Akuntansi Dan Keuangan, 3(1), 603-616.

Prihatiningtias, Y. W., \& Dayanti, N. (2014). Corporate Social Responsibility Disclosure and Firm Financial Performance In Mining And Natural Resources Industry. The International Journal of Accounting and Business Society, 22(1), 3559.

Priyatno, D. (2010). Teknik Mudah dan Cepat Melakukan Analisis Data Penelitian dengan SPSS dan Tanya Jawab Ujian Pendadaran. Yogyakarta: Gaya Media.

Rahman, M., Rodríguez-Serrano, M. Á., \& Lambkin, M. (2019). Brand equity and firm performance: the complementary role of corporate social responsibility. Journal of Brand Management, (March).

Riadi, E. (2016). Statistika Penelitian (Analisis Manual dan IBM SPSS). Yogyakarta: CV. Andi Offset.

Sarita, B., Takdir, D. S., Sujono, \& Sabrin. (2016). The Effect of Profitability on Firm Value in Manufacturing Company at Indonesia Stock Exchange. The International Journal Of Engineering And Science, 5(10), 2319-1813.

Sivasubramaniam, S. (2019). Corporate Social Responsibility and Firm Performance of Licensed Commercial Banks in Sri Lanka. (April).

Sugiyono. (2009). Metode Penelitian Kuantitatif, Kualitatif dan RED. Bandung: Alfabeta.

Sujarweni, V. W. (2015). Metode Penelitian Bisnis dan Ekonomi. Yogyakarta: Pustaka Baru Press.

Susila, M. P., \& Prena, G. Das. (2019). Pengaruh Keputusan Pendanaan, Kebijakan Dividen, Profitabilitas Dan Corporate Social Responsibility Terhadap Nilai Perusahaan. Jurnal Akuntansi : Kajian Ilmiah Akuntansi (JAK), $6(1), 80$.

Westerfield, S., Brandford, R., \& Jordan. (2008). Pengantar Keuangan Perusahaan (Corporate Finance Fundamentals). Jakarta: Salemba Empat.

Wijaya, B.I., Sedana, I. B. . (2015). Pengaruh Profitabilitas Terhadap Nilai 
Perusahaan (Kebijakan Dividen dan Kesempatan Investasi Sebagai Variabel Mediasi). E-Jurnal Manajemen Unud, 4(12), 4477-4500. 